\title{
Feeding-related controls on microbial nitrogen cycling associated with the Arctic marine copepod Calanus hyperboreus
}

\author{
Peter Stief $^{1, *}$, Ann Sofie Birch Lundgaard ${ }^{1}$, Torkel Gissel Nielsen², Ronnie N. Glud ${ }^{1,3}$ \\ ${ }^{1}$ University of Southern Denmark, Department of Biology, Nordcee, Campusvej 55, 5230 Odense M, Denmark \\ ${ }^{2}$ Technical University of Denmark, DTU AQUA, Kemitorvet, 2800 Kgs. Lyngby, Denmark \\ ${ }^{3}$ Department of Ocean and Environmental Sciences, Tokyo University of Marine Science and Technology, 108-8477 Tokyo, Japan
}

ABSTRACT: The copepod Calanus hyperboreus, a key species of Arctic marine ecosystems, has a partially anoxic gut that is suspected to host anaerobic microbial activities. So far, however, only dead specimens have been studied in which gut processes are quickly abolished by microbial carcass degradation. Here, live specimens were exposed to different feeding regimes and ambient oxygen levels to study the controls on copepod-associated microbial nitrogen cycling in ${ }^{15} \mathrm{~N}$-enrichment experiments. Algae-fed copepods exhibited consistently high rates of denitrification and low or variable rates of dissimilatory nitrate reduction to ammonium (or nitrite), nitrification, and nitrous oxide release. Thus, live C. hyperboreus contribute to pelagic fixed-nitrogen loss through denitrification that is otherwise absent from oxygenated Arctic surface waters. The feeding-related controls on copepod-associated anaerobic nitrogen cycling are supported by significantly reduced rates in starved copepods. In addition, freshly released fecal pellets showed similar patterns of nitrogen cycling as fed copepods. Unlike in previous studies on copepod carcasses, low ambient oxygen levels did not stimulate anaerobic nitrogen cycling in live specimens, supporting that the $C$. hyperboreus gut is anoxic, irrespective of ambient oxygen levels. Fecal pellets and carcasses retained denitrification activity for $4 \mathrm{~d}$ of simulated sinking. We estimate that during the time of the Arctic spring bloom, pelagic denitrification associated with live specimens, fecal pellets, and carcasses of $C$. hyperboreus is equivalent to $\sim 12 \%$ of the benthic fixed-nitrogen loss. This estimate increases to $\sim 28 \%$, provided that the abundant sibling species $C$. glacialis and C. finmarchicus exhibit denitrification activities in proportion to their smaller body size.

${ }^{*}$ Corresponding author: peterstief@biology.sdu.dk

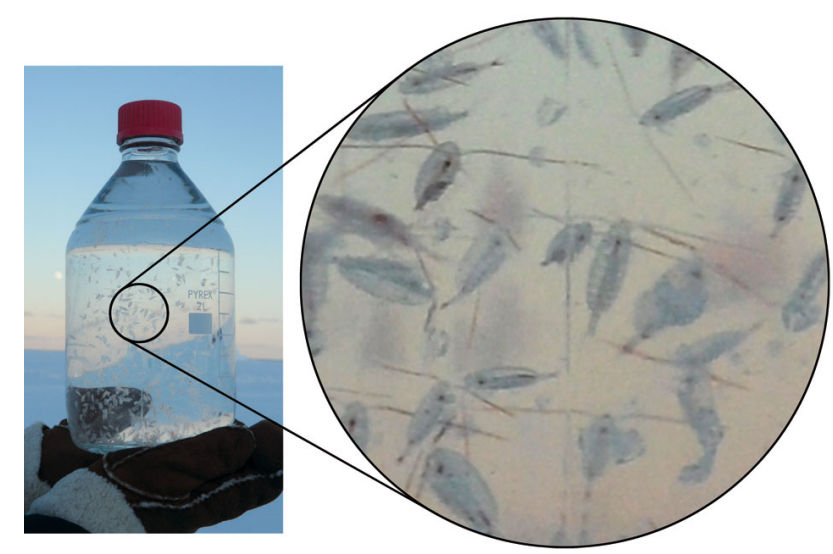

A bottle full of copepods dominated by Calanus hyperboreus specimens (collected in Disko Bay, West Greenland) in which microbial denitrification activity was found.

Photo: Peter Stief

KEY WORDS: Copepods - Arctic $\cdot$ Denitrification · Nitrification · Nitrous oxide · Oxygen · Feeding · Fecal pellets $\cdot$ Carcasses $\cdot{ }^{15} \mathrm{~N}$ stable-isotope labeling

\section{INTRODUCTION}

The zooplankton community in Arctic marine ecosystems is dominated by the co-occurring calanoid copepod species Calanus hyperboreus, C. glacialis, and C. finmarchicus (Hirche 1991, Madsen et al. 2001). The timing of the Arctic phytoplankton spring bloom dictates the life cycle of these herbivores, which show peak abundances in surface waters

() The authors 2018. Open Access under Creative Commons by Attribution Licence. Use, distribution and reproduction are unrestricted. Authors and original publication must be credited. 
around the time of the bloom (Conover 1988, Swalethorp et al. 2011). Aside from holding a central position in the Arctic food chain (Falk-Petersen et al. 2009), calanoid and other copepods play an important role in pelagic biogeochemistry as colonization sites for diverse microorganisms (Møller et al. 2007, Tang et al. 2010, Turner 2015). Major biogeochemical implications of the elevated microbial densities and activities on copepods include mineralization and respiration processes that may result in microscale $\mathrm{O}_{2}$ depletion inside the gut (Tang et al. 2011), decaying carcasses (Glud et al. 2015), and fecal pellets (Alldredge \& Cohen 1987), despite high $\mathrm{O}_{2}$ levels in the surrounding water. Notably, the potentially anoxic interior of copepods and fecal pellets might host anaerobic microbial activities that are not present in the oxygenated water column.

Recently, intense anaerobic nitrogen cycling (Ncycling) was demonstrated in sinking phytodetritus aggregates that had an anoxic center, especially when exposed to low-oxygen conditions (Klawonn et al. 2015, Kamp et al. 2016, Stief et al. 2016). Similarly, sinking carcasses of diverse copepod species from different aquatic ecosystems displayed significant anaerobic N-cycling (Glud et al. 2015, Stief et al. 2017 , 2018). The rates of carcass-associated anaerobic Ncycling increased with decreasing $\mathrm{O}_{2}$ concentrations in the surrounding water, suggesting that the spatial extent of internal anoxia in copepod carcasses is mainly controlled by ambient $\mathrm{O}_{2}$ levels. In $C$. finmarchicus carcasses, for instance, denitrification activity increased exponentially with decreasing ambient $\mathrm{O}_{2}$ levels (Glud et al. 2015). The denitrification pathway reduces $\mathrm{NO}_{3}^{-}$to $\mathrm{N}_{2}$ gas, which leads to fixed-nitrogen loss from aquatic ecosystems because of the relatively low bioavailability of $\mathrm{N}_{2}$. In small marine and freshwater copepod carcasses, dissimilatory nitrate reduction to ammonium (DNRA) and dissimilatory nitrate reduction to nitrite (DNRN) appear to be important anaerobic N-cycle pathways (Stief et al. 2017, 2018). These 2 pathways do not directly contribute to fixed-nitrogen loss. In strictly anoxic settings, however, carcass-associated DNRA and DNRN may supply free-living anammox bacteria with $\mathrm{NH}_{4}{ }^{+}$ and $\mathrm{NO}_{2}{ }^{-}$, respectively, which are then converted to $\mathrm{N}_{2}$ (Thamdrup 2012). Copepod carcasses may thus contribute directly and indirectly to pelagic fixednitrogen loss, depending on the microbial populations colonizing them and the ambient $\mathrm{O}_{2}$ levels. Fixed-nitrogen loss coupled to pelagic microsites is commonly overlooked by incubation-based rate measurements due to pre-filtration of water samples or small incubation volumes that exclude the presence of copepods, fecal pellets, and phytodetritus aggregates. Thus, by taking into account the fixed-nitrogen loss coupled to copepods and other pelagic microsites, the models of oceanic nitrogen dynamics might be considerably improved, especially for low-oxygen environments (Bianchi et al. 2018).

For calanoid copepods in subarctic waters, a relative carcass abundance of $\sim 25 \%$ has been found (Yamaguchi et al. 2002). Daase et al. (2014) report highly variable relative carcass abundances ranging from $9-14 \%$ in an Arctic fjord to as high as $94 \%$ in a basin of the Arctic Ocean at 200-3000 m water depth. Thus, the total contribution of copepods to pelagic Ncycling is in any case higher than estimated from rate measurements with carcasses only. It is not known, however, whether live copepods display the same Ncycling patterns and rates as dead copepods. Anaerobic N-cycling is expected to occur either inside the anoxic gut of live copepods (Tang et al. 2011), or inside the disintegrating body of dead copepods (Glud et al. 2015, Stief et al. 2017, 2018). In either case, internal anoxia may establish due to high $\mathrm{O}_{2}$ consumption rates of microorganisms colonizing the copepods, whereas labile organic carbon would be either food derived and continuously supplied by the copepod's feeding activity, or body derived and thus finite.

In this study, the hypothesis is tested that anaerobic $\mathrm{N}$-cycling associated with the large marine copepod C. hyperboreus is subject to feeding-related controls. To this end, live copepods were exposed to different feeding regimes and the rates of anaerobic $\mathrm{N}$-cycling were measured in ${ }^{15} \mathrm{~N}$-incubations. In addition, live copepods were exposed to low-oxygen conditions to test whether anaerobic N-cycling in the gut or on the exoskeleton can be further stimulated or induced, respectively. Patterns of $\mathrm{N}$-cycling were compared between algae-fed copepods and freshly released fecal pellets. The persistence of anaerobic N-cycling associated with fecal pellets and copepod carcasses was followed for a simulated sinking period of $4 \mathrm{~d}$. The results of these experiments were used for a first assessment of the in situ contribution by live specimens, fecal pellets, and carcasses of C. hyperboreus to fixed-nitrogen loss in Arctic marine ecosystems.

\section{MATERIALS AND METHODS}

\section{Collection of study organisms}

Calanus hyperboreus was sampled in Disko Bay near the southern tip of Disko Island off West Green- 
land (69 $\left.14^{\prime} 15^{\prime \prime} \mathrm{N}, 53^{\circ} 31^{\prime} 15^{\prime \prime} \mathrm{W}\right)$ in April 2014, April 2015, and February 2016. Zooplankton was collected by vertical hauls (150-0 m) with a WP-2 zooplankton net (200 $\mu \mathrm{m}$ mesh size) with a large non-filtering cod end through a hole in the sea ice. Seawater was collected with a $30 \mathrm{l}$ Niskin bottle at $150 \mathrm{~m}$ water depth. During transport to the laboratory, zooplankton and seawater were kept at in situ temperature in a cooling box. Live females of $C$. hyperboreus were isolated in an ice-cooled tray within $\sim 6 \mathrm{~h}$ of collection. In a thermostated room $\left(2.5 \pm 0.5^{\circ} \mathrm{C}\right)$, the copepods were maintained at a density of 3 individuals (ind.) $\mathrm{l}^{-1}$ in $10 \mathrm{l}$ buckets filled with aerated in situ seawater and fed once per day with the cryptophyte Rhodomonas salina (2014) or the diatom Skeletonema marinoi (2015) until used for experiments at the Arctic Station (Qeqertarsuaq, Disko Island, Greenland; University of Copenhagen). In 2016, live copepods were transported to the University of Southern Denmark (Odense, Denmark) where they were used for experiments. These copepods were maintained at a density of 3 ind. $\mathrm{l}^{-1}$ in 11 bottles filled with aerated artificial seawater (ASW; Red Sea Aquatics) stored in a fridge $\left(4.0 \pm 0.5^{\circ} \mathrm{C}\right)$ and fed every second day with $S$. marinoi. Before each feeding event, one-third of the seawater in the maintenance buckets and bottles was discarded and replaced with fresh seawater and dead specimens were removed. The 2 algae species, $S$. marinoi (CCMP 1332, NCMA) and $R$. salina, had been cultured in F/2 medium prepared in 0.2- $\mu$ m-filtered, autoclaved seawater with and without silicate addition, respectively (Guillard \& Ryther 1962).
The maintenance density of C. hyperboreus of 3 ind. $\mathrm{l}^{-1}$ was high compared with in situ densities of up to 0.09 ind. $1^{-1}$ as observed in Disko Bay during the spring bloom (Swalethorp et al. 2011), but similar to very high calanoid copepod densities encountered in single net hauls (Madsen et al. 2001). The animals appeared to behave and feed normally as most specimens had completely filled guts when retrieved for experiments. Respiration and excretion rates were within the previously reported ranges (Gilfillan et al. 1986, Auel et al. 2003) and were not significantly different between specimens maintained in large and small maintenance containers (respiration: $t=0.053, \mathrm{df}=29$, $\mathrm{p}=0.958$; excretion: $t=-0.017, \mathrm{df}=20, \mathrm{p}=0.987$ ).

\section{Overview and preparation of experiments}

${ }^{15} \mathrm{~N}$-stable-isotope enrichment experiments in natural seawater or in ASW were made with live and dead specimens and fecal pellets of $C$. hyperboreus (if applicable, fed with $R$. salina or $S$. marinoi) depending on availability of animals, algae, and seawater during 3 measurement campaigns in 2014, 2015, and 2016 (Table 1).

- The effect of filled versus empty gut (i.e. gut filling degree) of live specimens on copepod-associated $\mathrm{N}$-cycling was addressed in 2 experimental series. In 2014, the algae-fed group of copepods was fed with $R$. salina at a saturating cell density of $\sim 50000$ cells $\mathrm{ml}^{-1}$ at least $24 \mathrm{~h}$ before and also during ${ }^{15} \mathrm{NO}_{3}{ }^{-}$-incubations in non-filtered seawater,

Table 1. Overview of experiments on microbial nitrogen cycling associated with Calanus hyperboreus (fed with Rhodomonas salina or Skeletonema marinoi) and its fecal pellets and carcasses. Wet wt: wet weight of single specimens; data are means \pm SE of 3-12 batches of 1-3 specimens. ASW: artificial seawater. Oxic: $85-95 \%$ air saturation (AS); hypoxic: 10-25\% AS; near-anoxic: $0-4 \%$ AS

\begin{tabular}{|c|c|c|c|c|c|c|c|c|}
\hline Year & \multicolumn{2}{|c|}{ Seawater } & ${ }^{15} \mathrm{~N}$-tracer & \multicolumn{2}{|c|}{ Experimental treatments } & $\begin{array}{l}\begin{array}{l}\text { Wet wt } \\
(\mathrm{mg})\end{array} \\
15.2 \pm 0.3\end{array}$ & $\begin{array}{c}\mathrm{n} \\
(20)\end{array}$ & $\begin{array}{l}\begin{array}{l}\text { Algae } \\
\text { species }\end{array} \\
\text { R. salina }\end{array}$ \\
\hline 2014 & $\begin{array}{l}\text { Disko Bay } \\
(150 \mathrm{~m})\end{array}$ & Unfiltered & ${ }^{15} \mathrm{NO}_{3}^{-}(10 \mu \mathrm{M})$ & $\begin{array}{l}\text { Live copepods } \\
\text { Dead copepods } \\
\text { Fecal pellets }\end{array}$ & $\begin{array}{l}\text { Algae-fed, oxic } \\
\text { Algae-starved, oxic } \\
\text { Algae-fed, hypoxic } \\
\text { Fresh } \\
\text { Aged } \\
\text { Fresh } \\
\text { Aged }\end{array}$ & $\begin{array}{l}15.2 \pm 0.3 \\
16.3 \pm 0.5 \\
15.1 \pm 1.0 \\
11.8 \pm 1.4 \\
10.4 \pm 1.5 \\
\text { No data } \\
\text { No data }\end{array}$ & $\begin{array}{l}(20) \\
(20) \\
(14) \\
(12) \\
(12)\end{array}$ & $\begin{array}{l}\text { R. salina } \\
- \\
R . \text { salina } \\
R . \text { salina } \\
R . \text { salina } \\
R . \text { salina } \\
\text { R. salina }\end{array}$ \\
\hline 2015 & $\begin{array}{l}\text { Disko Bay } \\
(150 \mathrm{~m})\end{array}$ & $\begin{array}{l}\text { Unfiltered } \\
\text { Unfiltered } \\
0.2 \mu \mathrm{m} \text { filtered }\end{array}$ & $\begin{array}{c}{ }^{15} \mathrm{NO}_{2}{ }^{-}(5 \mu \mathrm{M}) \\
\text { or } \\
{ }^{15} \mathrm{NH}_{4}^{+}(5 \mu \mathrm{M})\end{array}$ & Live copepods & $\begin{array}{l}\text { Algae-fed, oxic } \\
\text { Algae-starved, oxic } \\
\text { Bacteria-starved, oxic }\end{array}$ & $\begin{array}{l}13.8 \pm 1.0 \\
11.9 \pm 0.7 \\
13.0 \pm 0.4\end{array}$ & $\begin{array}{l}(15) \\
(15) \\
(15)\end{array}$ & $\begin{array}{l}\text { S. marinoi } \\
- \\
-\end{array}$ \\
\hline 2016 & ASW & $0.2 \mu \mathrm{m}$ filtered & ${ }^{15} \mathrm{NO}_{2}{ }^{-}(5 \mu \mathrm{M})$ & Live copepods & $\begin{array}{l}\text { Algae-fed, oxic } \\
\text { Algae-fed, near } \\
\text { anoxic }\end{array}$ & $13.4 \pm 1.1$ & (30) & $\begin{array}{l}\text { S. marinoi } \\
\text { S. marinoi }\end{array}$ \\
\hline
\end{tabular}


while the algae-starved control group was kept in non-filtered seawater without algae addition. In 2015, the algae-fed group of copepods was fed with $S$. marinoi at a saturating cell density of $\sim 15000$ cells $\mathrm{ml}^{-1}$ at least $24 \mathrm{~h}$ before and also during ${ }^{15} \mathrm{NO}_{2}^{-}$incubations in non-filtered seawater, while the algaestarved and the bacteria-starved control groups were kept in non-filtered seawater without algae addition and in $0.2-\mu \mathrm{m}$-filtered seawater with all bacteria removed, respectively. The particulate organic carbon (POC) levels in the 2 algae-fed treatments in the 2014 and 2015 measurement campaigns were estimated at 1.125 and $1.15 \mu \mathrm{g} \mathrm{C} \mathrm{ml}^{-1}$, respectively (Olenina et al. 2006). The POC levels in the algae-starved and bacteria-starved control groups were estimated at 0.03 and $0 \mu \mathrm{g} \mathrm{C} \mathrm{ml}^{-1}$, respectively (Fukuda et al. 1998). The gut filling degree of the transparent copepods was assessed visually and is reported as the percentage gut length that was filled with food particles.

- The effect of the ambient oxygen level on N-cycling associated with live copepods was studied in 2 experimental series. In 2014, algae-fed specimens were exposed to $85-95 \%$ (oxic) versus $10-25 \%$ air saturation (hypoxic) during ${ }^{15} \mathrm{NO}_{3}{ }^{-}$-incubations in non-filtered seawater. In 2016, algae-fed specimens were exposed to $85-95 \%$ (oxic) versus $0-4 \%$ air saturation (near anoxic) during ${ }^{15} \mathrm{NO}_{2}^{-}$-incubations in $0.2-\mu \mathrm{m}$-filtered ASW.

- N-cycling associated with fresh versus aged fecal pellets was studied in 2014 by feeding C. hyperboreus kept in a $10 \mathrm{l}$ bucket with $R$. salina for $24 \mathrm{~h}$ and then transferring the algae-fed specimens to a new bucket with non-filtered seawater. Fecal pellets that were released during the following $12 \mathrm{~h}$ and $96 \mathrm{~h}$, respectively, were collected by sieving onto a $125 \mu \mathrm{m}$ mesh. Afterwards, fecal pellets were incubated in ${ }^{15} \mathrm{NO}_{3}{ }^{-}$-enriched, non-filtered seawater under oxic conditions.

- $\mathrm{N}$-cycling associated with fresh versus aged carcasses (i.e. dead copepods) was studied in 2014 after killing algae-fed specimens in deoxygenated seawater for $1 \mathrm{~h}$ and then keeping them suspended in aerated, non-filtered seawater on a plankton wheel for $24 \mathrm{~h}$ and $96 \mathrm{~h}$, respectively. Afterwards, the carcasses were incubated in ${ }^{15} \mathrm{NO}_{3}{ }^{-}$-enriched, non-filtered seawater under oxic conditions. Note that only about one-third of the specimens died during the $1 \mathrm{~h}$ exposure to anoxia.

Live and dead copepods were incubated in batches of $1-3$, while fecal pellets were incubated in batches of $60-120$ in $25 \mathrm{ml}$ glass bottles (see next section). Control experiments without copepods and fecal pel- lets were run in parallel in non-filtered (if applicable, containing $R$. salina or $S$. marinoi) or $0.2-\mu \mathrm{m}$-filtered seawater.

\section{Rate measurements}

The live and dead copepods and fecal pellets that had been prepared as described in the previous section were used in $24 \mathrm{~h}$ incubation experiments for quantification of their $\mathrm{O}_{2}$ and $\mathrm{N}$-turnover rates. The $25 \mathrm{ml}$ glass bottles that were used as incubation vials had oxygen-sensitive optodes (SensorSpot, PyroScience) fixed on the inside, which allowed contactless $\mathrm{O}_{2}$ measurements (Firesting, PyroScience). The bottles were filled with seawater that was specifically adjusted for each incubation experiment regarding filtration, ${ }^{15} \mathrm{~N}$-tracer amendment, algae addition, and ambient $\mathrm{O}_{2}$ level (Table 1). Filtration of seawater for removal of microorganisms was done with Monta Mil@ nylon membrane filters $(0.2 \mu \mathrm{m}$; Frisenette) and using acid-washed glassware. ${ }^{15} \mathrm{~N}$-tracers (SigmaAldrich) were added at final concentrations of $10 \mu \mathrm{M}$ $\left({ }^{15} \mathrm{NO}_{3}{ }^{-}\right)$and $5 \mu \mathrm{M}\left({ }^{15} \mathrm{NO}_{2}{ }^{-},{ }^{15} \mathrm{NH}_{4}{ }^{+}\right)$. Background $\mathrm{NO}_{3}{ }^{-}$concentrations in the in situ and ASW were 13.2 $\mu \mathrm{M}$ and $1.3 \mu \mathrm{M}$, respectively. Background $\mathrm{NO}_{2}{ }^{-}$ and $\mathrm{NH}_{4}{ }^{+}$concentrations were generally $<0.2 \mu \mathrm{M}$. The addition of ${ }^{15} \mathrm{NO}_{2}{ }^{-}$and ${ }^{15} \mathrm{NO}_{3}{ }^{-}$increased the in situ concentration of oxidized dissolved inorganic nitrogen by $38 \%$ and $76 \%$, respectively, which may have stimulated the activity of anaerobic $\mathrm{N}$-cycle pathways to some degree. The added dose of ${ }^{15} \mathrm{NO}_{2}{ }^{-}$ was not expected to have toxic effects on copepods and bacteria, since the lethal concentration that kills $50 \%$ of the exposed population $\left(\mathrm{LC}_{50}\right)$ is at least $1-2$ and 3-4 orders of magnitude higher, respectively, than used here (Camargo \& Alonso 2006, Lotti et al. 2012). The addition of ${ }^{15} \mathrm{NH}_{4}{ }^{+}$was high compared with in situ $\mathrm{NH}_{4}{ }^{+}$concentrations, which may have stimulated nitrification activity substantially, but the nitrification rates measured here were still very low.

The algae-fed treatments received aliquots of the respective algae culture to arrive at cell densities of $R$. salina $\left(\sim 50000\right.$ cells $\left.\mathrm{ml}^{-1}\right)$ and $S$. marinoi $\left(\sim 15000\right.$ cells $\left.\mathrm{ml}^{-1}\right)$. Before addition, algae cultures were washed to remove excess nutrients. To this end, the cultures were centrifuged $(1000 \times g, 20 \mathrm{~min})$, resuspended in seawater, and subsampled for microscopic cell counts. After algae addition, the seawater was split into 2 portions, one to be degassed for 20 min with $\mathrm{O}_{2}$ and the other one with $\mathrm{He}$ or $\mathrm{Ar}$ (depending on availability). Degassing served to (1) lower the natural $\mathrm{N}_{2}$ background for improving 
denitrification measurements at low rates and (2) allow the adjustment of the targeted ambient $\mathrm{O}_{2}$ level by mixing the appropriate volumes of $\mathrm{O}_{2}$ - and $\mathrm{He}$ - or Ar-flushed seawater. This procedure worked for most of the experiments, with the exception of the denitrification measurements in 2015 because the used Ar gas had a higher ${ }^{30} \mathrm{~N}_{2}:{ }^{28} \mathrm{~N}_{2}$ ratio than air.

The $25 \mathrm{ml}$ glass bottles were filled with the prepared seawater, copepods, or fecal pellets and sealed with butyl rubber stoppers without entrapping gas bubbles. The bottles were mounted on a plankton wheel to keep the copepods, fecal pellets, or carcasses in suspension and were then incubated in darkness at $2.5 \pm 0.5^{\circ} \mathrm{C}$ for up to $24 \mathrm{~h}$. This incubation temperature is very similar to the in situ temperature that $C$. hyperboreus is exposed to in Disko Bay at a water depth of $150 \mathrm{~m}$ during spring-early summer (Swalethorp et al. 2011). At time intervals of 1.5-3.0 h for the first 6-12 $\mathrm{h}$ and again at the end of the incubations (i.e. after $24 \mathrm{~h}$ ), $\mathrm{O}_{2}$ measurements were made and water samples for $\mathrm{N}$-analyses were withdrawn through the stopper as described in detail in Stief et al. (2016). Ambient $\mathrm{O}_{2}$ concentrations were maintained at stable levels by re-injecting seawater adjusted to an $\mathrm{O}_{2}$ concentration that would compensate the concentration decrease observed since the last sampling time point (Fig. S1 in the Supplement at www.int-res.com/articles/suppl/m602p001_supp.pdf). The water sample withdrawn was used for analyses of $\mathrm{N}_{2}, \mathrm{~N}_{2} \mathrm{O}, \mathrm{NO}_{3}{ }^{-}, \mathrm{NO}_{2}{ }^{-}$, and $\mathrm{NH}_{4}{ }^{+}$.

\section{Nitrogen analyses}

Nitrate plus nitrite concentrations were measured on a $\mathrm{NO}_{\mathrm{x}}$ analyzer (CLD 60, Eco Physics) using the $\mathrm{VCl}_{3}$ reduction assay (Braman \& Hendrix 1989). Nitrite concentrations were measured with the Griess reaction and using a microplate reader (Multiskan GO Photometer, Thermo Fisher Scientific) after García-Robledo et al. (2014). Nitrate concentrations were then obtained by subtraction. Ammonium was analyzed with the salicylate method (Bower \& HolmHansen 1980). Isotopically labeled dinitrogen $\left({ }^{15} \mathrm{~N}\right.$ $\mathrm{N}_{2}$ ) was analyzed in the headspace of $3 \mathrm{ml}$ exetainers (Labco) on a gas chromatography-isotopic ratio mass spectrometer (Thermo Delta V Plus, Thermo Fisher Scientific) (Dalsgaard et al. 2012) with the excess above natural abundance calculated according to Nielsen (1992). Nitrous oxide concentrations were measured in the headspace of the same exetainers on a gas chromatograph (GC 7890, Agilent Technologies) and corrected for the prior headspace sampling for ${ }^{15} \mathrm{~N}-\mathrm{N}_{2}$ analysis and the proportion of $\mathrm{N}_{2} \mathrm{O}$ dissolved in the seawater. ${ }^{15} \mathrm{~N}$-labeled $\mathrm{NO}_{3}{ }^{-}, \mathrm{NO}_{2}{ }^{-}$, and $\mathrm{NH}_{4}{ }^{+}$were analyzed with the cadmium/sulfamic acid, sulfamic acid, and hypobromite assay, respectively (Warembourg 1993, McIlvin \& Altabet 2005, Füssel et al. 2012).

\section{Calculations and statistics}

Rates of oxygen and nitrogen turnover in the $25 \mathrm{ml}$ bottles were calculated from linear concentration changes, which in many cases were limited to the first $4-5$ sampling time points (i.e. until $8-12 \mathrm{~h}$ after the start of the incubations). The dilution effect on solutes and gases caused by the sampling process was accounted for in the calculations (Stief et al. 2016). Oxygen and nitrogen turnover directly associated with the copepods and fecal pellets were approximated by subtracting turnover rates (if any) measured in control incubations with seawater only.

The total denitrification rate $\left(\mathrm{P}^{\mathrm{Total}} \mathrm{N}_{2}\right)$ was calculated from ${ }^{15} \mathrm{NO}_{3}{ }^{-}$and ${ }^{15} \mathrm{NO}_{2}{ }^{-}$incubations using the principles of random isotope pairing in the absence of anammox (Nielsen 1992) as $\mathrm{P}^{\text {Total }} \mathrm{N}_{2}=\left(\mathrm{P}^{29} \mathrm{~N}_{2}\right)^{2}$ / $\left(4 \times \mathrm{P}^{30} \mathrm{~N}_{2}\right)+\mathrm{P}^{29} \mathrm{~N}_{2}+\mathrm{P}^{30} \mathrm{~N}_{2}$. The concurrent production of ${ }^{15} \mathrm{~N}-\mathrm{N}_{2},{ }^{15} \mathrm{NO}_{2}{ }^{-}$, and ${ }^{15} \mathrm{NH}_{4}{ }^{+}$indicated that aside from denitrification, DNRN and DNRA were also occurring (i.e. rather than ${ }^{15} \mathrm{NO}_{3}{ }^{-}$assimilation followed by ${ }^{15} \mathrm{NO}_{2}{ }^{-}$and ${ }^{15} \mathrm{NH}_{4}{ }^{+}$recycling due to the decay of microbial biomass, which would have occurred with a time delay). The net DNRN rate was calculated from the ${ }^{15} \mathrm{NO}_{2}{ }^{-}$production rate divided by the initial ${ }^{15} \mathrm{NO}_{3}{ }^{-}$-labeling fraction in ${ }^{15} \mathrm{NO}_{3}{ }^{-}$incubations. The net DNRA rate was calculated from the ${ }^{15} \mathrm{NH}_{4}{ }^{+}$production rate divided by the initial ${ }^{15} \mathrm{NO}_{3}{ }^{-}$- or ${ }^{15} \mathrm{NO}_{2}{ }^{-}$-labeling fraction in ${ }^{15} \mathrm{NO}_{3}{ }^{-}$and ${ }^{15} \mathrm{NO}_{2}{ }^{-}$incubations, respectively. The nitrification rate was calculated in 2 ways: (1) for ${ }^{15} \mathrm{NH}_{4}{ }^{+}$incubations, the ${ }^{15} \mathrm{NO}_{3}{ }^{-}+{ }^{15} \mathrm{NO}_{2}{ }^{-}$production rate was divided by the initial ${ }^{15} \mathrm{NH}_{4}{ }^{+}$-labeling fraction to arrive at the total nitrification rate; and (2) for ${ }^{15} \mathrm{NO}_{3}{ }^{-}$incubations, the ${ }^{14} \mathrm{NO}_{3}{ }^{-}$production rate was calculated as the temporal change in the difference between the total $\mathrm{NO}_{3}{ }^{-}$concentration and the ${ }^{15} \mathrm{NO}_{3}{ }^{-}$concentration to arrive at the rate of $\mathrm{NO}_{2}{ }^{-}$ oxidation, the second step of nitrification. The net $\mathrm{NH}_{4}{ }^{+}$release rate was calculated from the increase in total $\mathrm{NH}_{4}{ }^{+}$concentrations. No data are available for (1) DNRN in 2015 and 2016 due to lack of ${ }^{15} \mathrm{NO}_{3}{ }^{-}$ incubations and (2) denitrification in 2015 due to the excessively high ${ }^{30} \mathrm{~N}_{2}:{ }^{28} \mathrm{~N}_{2}$ ratio of the used Ar gas (see previous section). 
Significant differences in mean rates that had been measured in independent treatments were determined by Student's $t$-tests ( 2 factor levels) and 1-way ANOVA (3 factor levels) with $\alpha=0.05$. Homogeneity of variances was tested with Levene's test and, depending on the outcome, Tukey's and Games-Howell's tests for homogeneous and non-homogeneous variances, respectively, were used as posterior tests. Significant differences in mean rates that had been measured at 3 consecutive time points in the same experiment were determined by paired-sample $t$-tests with a Bonferroni-corrected $\alpha=0.05 / 3$. One-sample $t$-tests with $\alpha=$ 0.05 were used to check whether rates were significantly different from zero. All statistical analyses were performed with SPSS Version 11.0.

\section{RESULTS}

\section{Nitrogen-cycle pathways}

In incubations with live, algae-fed Calanus hyperboreus from the campaign in 2014, the rates of $\mathrm{O}_{2}$ uptake and net $\mathrm{NH}_{4}{ }^{+}$release (as combined metabolic activities of the animal and its associated microorganisms) by far exceeded the rates of microbially mediated N-cycling (Fig. 1). The copepod-associated microbial N-cycling itself was clearly dominated by denitrification with activities 20 -fold higher than nitrification, DNRA, DNRN, and net $\mathrm{N}_{2} \mathrm{O}$ release. During the campaigns in 2015 and 2016, much higher DNRA rates were measured, which in 1 case rivaled denitrification rates (see below).

The patterns of $\mathrm{O}_{2}$ and $\mathrm{N}$-turnover associated with freshly released $(\leq 12 \mathrm{~h})$ fecal pellets resembled the patterns observed for algae-fed copepods, except for the complete absence of net $\mathrm{NH}_{4}{ }^{+}$release and nitrification activity (i.e. the rates equaled zero after subtraction of the minute rates measured in the respective controls). Based on reported length ranges of the gut and fecal pellets of female adults of 5.5-7.0 mm and 400-700 $\mu \mathrm{m}$, respectively (Urban-Rich 1999, Juul-Pedersen et al. 2006, Olli et al. 2007, Tang et al. 2011), we estimate that a completely filled gut corresponds to 10 fecal pellets. Nitrogen turnover rates of 10 freshly released (and then incubated under oxic conditions) fecal pellets make up as much as $40 \%$, $72 \%$, and $28 \%$ of copepod-associated denitrification, DNRA, and DNRN activity, respectively (Fig. 1). In contrast, fecal-pellet-associated microbial N-turnover rates make up only $7 \%$ of the copepod-associated net $\mathrm{N}_{2} \mathrm{O}$ release and $0 \%$ of net $\mathrm{NH}_{4}{ }^{+}$release and nitrification.

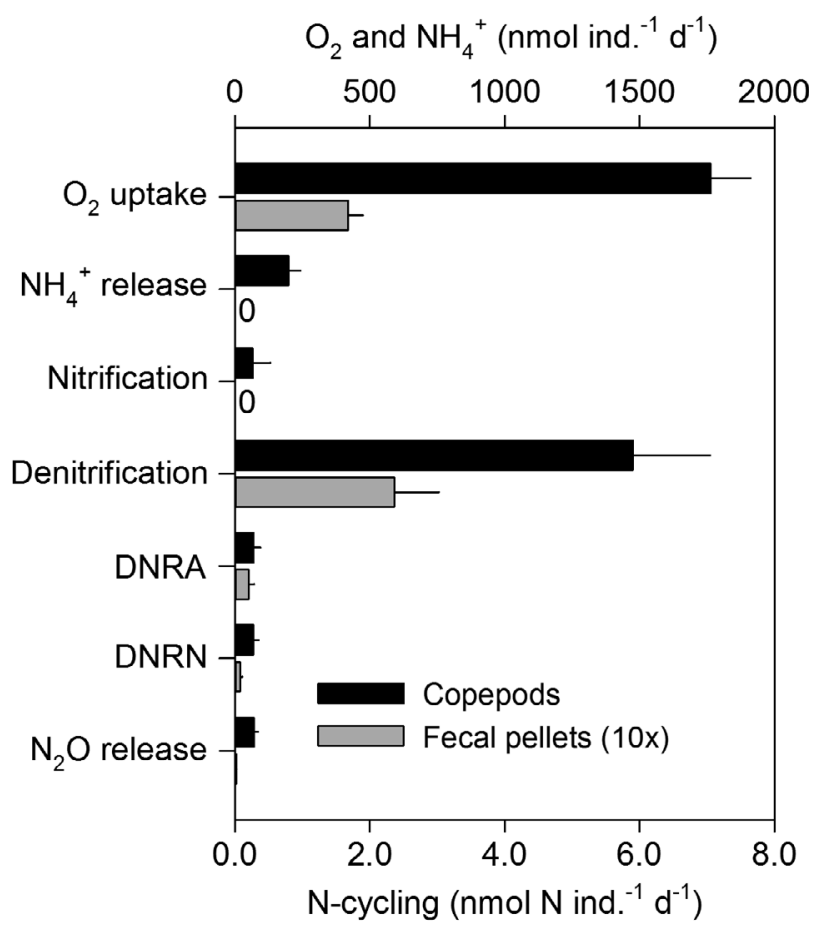

Fig. 1. Oxygen and nitrogen turnover associated with Calanus hyperboreus and its fecal pellets. Algae-fed copepods and freshly released fecal pellets were incubated in ${ }^{15} \mathrm{NO}_{3}{ }^{-}$enriched seawater under oxic conditions, in darkness, and at $2.5^{\circ} \mathrm{C}$ for up to $24 \mathrm{~h}$. Rates are expressed per 1 copepod specimen or per 10 fecal pellets. Means \pm SE of $n=12$ (copepods) and $n=5$ (fecal pellets) incubations are shown. Note different scales on the $2 x$-axes. DNRA/DNRN: dissimilatory nitrate reduction to ammonium/nitrite, respectively

Since only total $\mathrm{N}_{2} \mathrm{O}$ concentrations were measured by gas chromatography, the microbial $\mathrm{N}_{2} \mathrm{O}$ source could not be identified from any ${ }^{15} \mathrm{~N}$-labeling. Thus, the net $\mathrm{N}_{2} \mathrm{O}$ release by live copepods was plotted against nitrification and denitrification activity in search for covariation (Fig. 2A,B). However, no significant correlation was found between net $\mathrm{N}_{2} \mathrm{O}$ release and either nitrification or denitrification activity in 3 different live copepod treatments (Table S1 in the Supplement). Instead, highly significant correlations between net $\mathrm{N}_{2} \mathrm{O}$ and $\mathrm{NH}_{4}{ }^{+}$release were found for algae-fed and algae-starved copepods under oxic conditions (Fig. 2C, Table S1).

\section{Gut filling degree}

The starvation of copepods for algae before and during the ${ }^{15} \mathrm{~N}$-incubations reduced the gut filling degree from $81.3 \pm 6.3 \%$ (mean \pm standard error) to $5.0 \pm 1.7 \%$ (campaign in 2014) and from $56.3 \pm 14.4 \%$ 

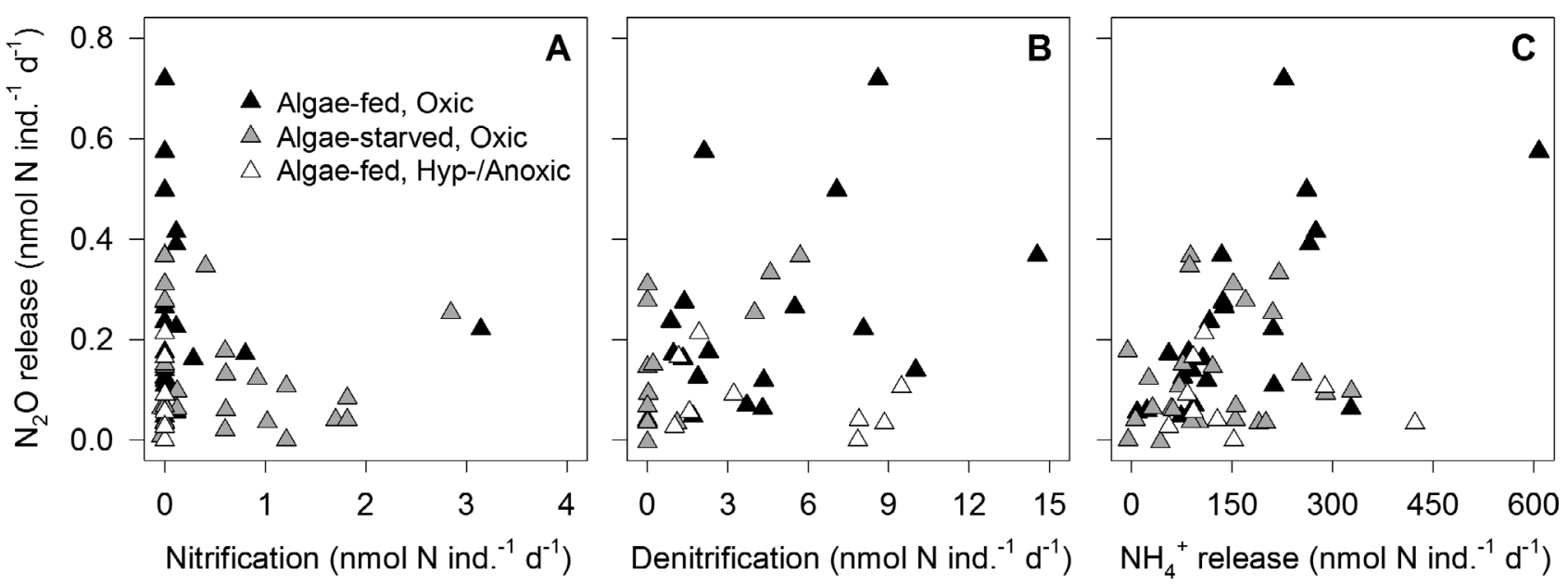

Fig. 2. Nitrous oxide release from Calanus hyperboreus. Correlation between net $\mathrm{N}_{2} \mathrm{O}$ release and (A) nitrification activity, (B) denitrification activity, and (C) net $\mathrm{NH}_{4}{ }^{+}$release associated with live copepods. Incubation conditions as specified in 'Materials and methods' and Table 1 . The only significant correlations were found between net $\mathrm{N}_{2} \mathrm{O}$ release and $(\mathrm{C}) \mathrm{net}_{\mathrm{NH}}{ }^{+}$ release by algae-fed and algae-starved specimens under oxic conditions (Table S1 in the Supplement)

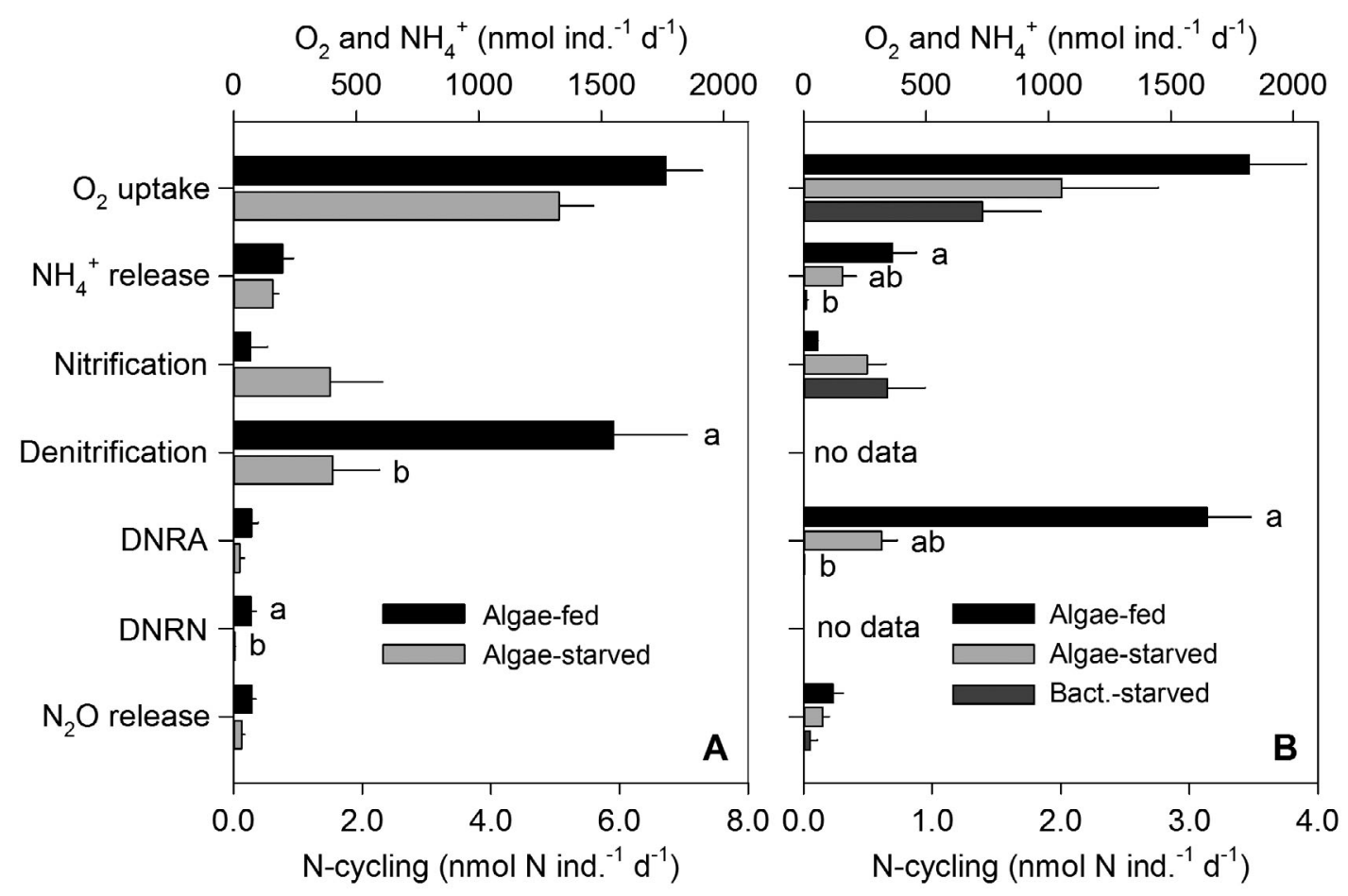

Fig. 3. Effect of gut filling degree. Algae-fed, algae-starved, and bacteria-starved Calanus hyperboreus were incubated in (A) ${ }^{15} \mathrm{NO}_{3}{ }^{-}$-enriched or (B) ${ }^{15} \mathrm{NO}_{2}^{-}$-enriched seawater. Incubation conditions as specified in 'Materials and methods' and Table 1. Means \pm SE of $n=5-12$ (algae fed), $n=5-10$ (algae starved), and $n=5$ (bacteria starved) incubations are shown. Note different scales on the $2 x$-axes. Lower-case letters indicate statistically significant differences between algae-fed, algae-starved, and bacteria-starved copepods. DNRA/DNRN: dissimilatory nitrate reduction to ammonium/nitrite, respectively

to $5.0 \pm 3.3 \%$ (campaign in 2015). The additional starvation of copepods for seawater bacteria and particles larger than $0.2 \mu \mathrm{m}$ reduced the gut filling degree further to $3.3 \pm 2.0 \%$ (campaign in 2015). The reduced gut filling degree led to significantly reduced rates of denitrification, DNRA, DNRN, and net $\mathrm{NH}_{4}{ }^{+}$ release (Fig. 3; Table S2 in the Supplement), though not necessarily in both measurement campaigns (i.e. DNRA and $\mathrm{NH}_{4}{ }^{+}$release). Rates of $\mathrm{O}_{2}$ uptake, nitrification, and net $\mathrm{N}_{2} \mathrm{O}$ release were not significantly 
changed by differences in the gut filling degree (Fig. 3, Table S2).

\section{Ambient oxygen level}

Oxic (85-95\% air saturation), hypoxic (10-25\% air saturation), and near-anoxic (0-4\% air saturation) conditions were tested for their effect on copepod-associated, anaerobic N-cycling that may be stimulated by the expansion of internal anoxia under low-oxygen conditions (Fig. 4). Note that in the near-anoxic treatment, fully anoxic conditions were achieved at the last sampling time point (Fig. S1C). In any case, no significant effect of low-oxygen conditions on denitrification, DNRA, and DNRN was observed (Fig. 4A,B; Table S3 in the Supplement), which supports that the gut of $C$. hyperboreus is anoxic even at high ambient $\mathrm{O}_{2}$ levels. In contrast, low-oxygen conditions led to significantly lower rates of copepod-associated net $\mathrm{N}_{2} \mathrm{O}$ release (Fig. 4, Table S3) and nitrification rates that equaled zero (Fig. 4). Taken together, these observations suggest that copepod-associated denitrification is not a source of $\mathrm{N}_{2} \mathrm{O}$, but nitrification potentially is. The mortality of $C$. hyperboreus was $\sim 70 \%$ at the end of the hypoxic treatment and $100 \%$ after $3 \mathrm{~h}$ of the near-anoxic treatment.

\section{Temporal trends}

Nitrogen cycling associated with copepods and fecal pellets was followed for $4 \mathrm{~d}$ after death and defecation, respectively (Fig. 5; Table S4 in the Supplement). One day after killing, $\mathrm{N}$-cycling rates were not significantly different between carcasses and live copepods, indicating that the relative partitioning between different $\mathrm{N}$ cycling pathways also remained the same (Fig. 5A, Table S4). Furthermore, N-cycling rates were not significantly different between 1-d-old and 4-d-old carcasses (Fig. 5A, Table S4). Noteworthy, the 4-d-old carcasses still remained net sinks of $\mathrm{NO}_{\mathrm{x}}{ }^{-}$(Fig. S2A in the Supplement). The wet weight of the 4-d-old carcasses was about one-third lower than that of live copepods (Table 1). The only significant change experienced by aging fecal pellets was a strong increase of nitrification activity (Fig. 5B, Table S4), which turned the fecal pellets from a net sink into a net source of $\mathrm{NO}_{\mathrm{x}}{ }^{-}$(Fig. S2B), despite the stable denitrification activity associated with fecal pellets (Fig. 5B, Table S4).
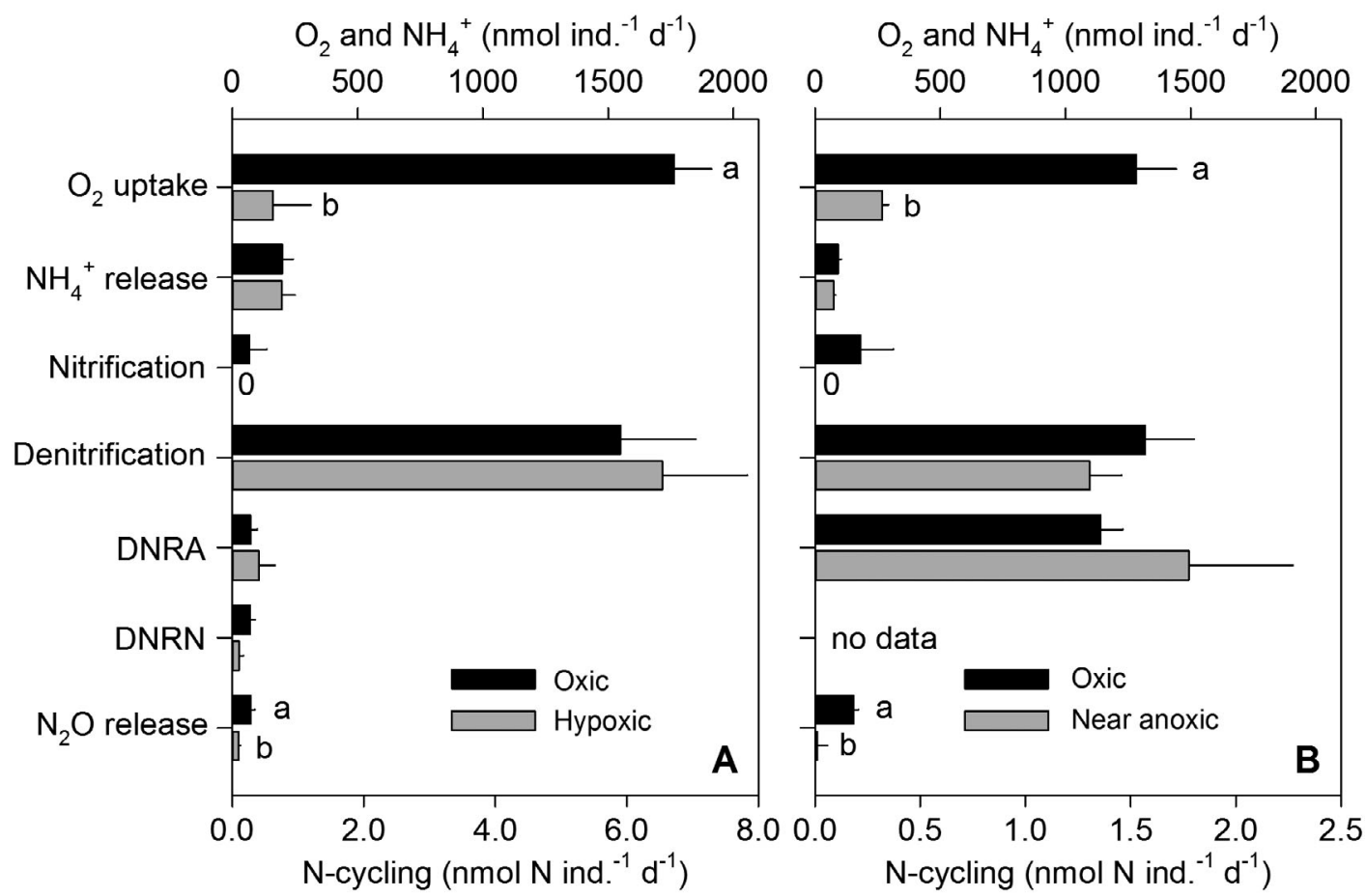

Fig. 4. Effect of ambient oxygen level. Algae-fed copepods Calanus hyperboreus were incubated in $(\mathrm{A}){ }^{15} \mathrm{NO}_{3}{ }^{-}-$enriched or (B) ${ }^{15} \mathrm{NO}_{2}{ }^{-}$-enriched seawater under oxic vs. hypoxic or near-anoxic conditions. Incubation conditions as specified in 'Materials and methods' and Table 1. Means \pm SE of $n=5-12$ (oxic), $n=6$ (hypoxic), and $n=5$ (near anoxic) incubations are shown. Note different scales on the $2 \mathrm{x}$-axes. Lower-case letters indicate statistically significant differences between oxic, hypoxic, and near-anoxic conditions. DNRA/DNRN: dissimilatory nitrate reduction to ammonium/nitrite, respectively 

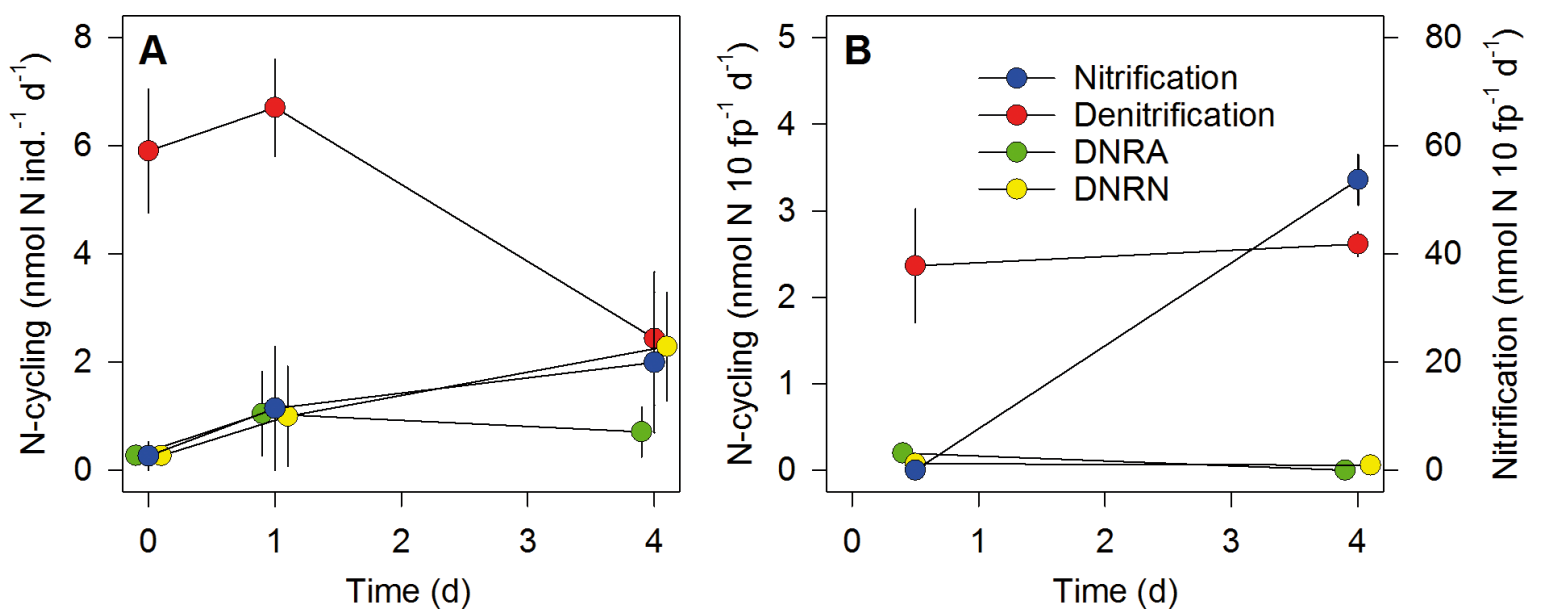

Fig. 5. Effect of time. The rates of different N-cycle pathways associated with (A) Calanus hyperboreus and (B) its fecal pellets were measured for up to $4 \mathrm{~d}$ after death and defecation, respectively, under incubation conditions as specified in 'Materials and methods' and Table 1. Means \pm SE of $n=12$ (live copepods), $n=6$ (dead copepods), and $n=3-5$ (fecal pellets) incubations are shown. Note that in (B), rates are expressed per 10 fecal pellets (fp) and nitrification activity is shown on a dedicated right-hand $y$-axis. DNRA/DNRN: dissimilatory nitrate reduction to ammonium/nitrite, respectively

\section{Contribution by calanoid copepods to fixed-nitrogen loss in Arctic waters}

The pelagic $\mathrm{N}_{2}$ production by live copepods (through denitrification) and the benthic $\mathrm{N}_{2}$ production in sediments (through denitrification and anammox) were compared on an areal basis (Table S5 in the Supplement). During the Arctic spring bloom, the depth-integrated in situ abundance of adult $C$. hyperboreus at a $250 \mathrm{~m}$ deep station in Disko Bay reaches maximum levels of $\sim 2250$ ind. $\mathrm{m}^{-2}$ (Swalethorp et al. 2011). For our extrapolation, $75 \%$ of the C. hyperboreus specimens were assumed to be alive and $25 \%$ dead (Yamaguchi et al. 2002). Denitrification associated with the live specimens amounts to $10 \mu \mathrm{mol} \mathrm{N} \mathrm{m}{ }^{-2} \mathrm{~d}^{-1}$ (Table S5), which is equivalent to $3.5 \%$ of the benthic $\mathrm{N}_{2}$ production (Rysgaard et al. 2004). However, the C. hyperboreus contribution increases to as much as $11.6 \%$, if denitrification activities of dead specimens and fecal pellets are included in the estimate (Table S5).

The other 2 calanoid copepod species in the Arctic, C. glacialis and C. finmarchicus, are even more abundant than C. hyperboreus (Hirche 1991, Madsen et al. 2001, Swalethorp et al. 2011), but they have a much smaller individual biomass (Hirche 1991, Madsen et al. 2001). Since denitrification activity has recently been found in carcasses of the small C. finmarchicus (Glud et al. 2015), it can be assumed that the medium-sized C. glacialis also exhibits denitrification activity. It can be further assumed that the gut volume decreases proportionately to biomass and therefore, the denitrification rates measured for $C$. hyperboreus were downscaled linearly to the much smaller individual biomass of C. glacialis and C. finmarchicus (Table S5). The total integrated denitrification activity associated with the 3 calanoid copepod species and their fecal pellets and carcasses amounts then to $82 \mu \mathrm{mol} \mathrm{N} \mathrm{m}{ }^{-2} \mathrm{~d}^{-1}$ (Table S5), which is equivalent to as much as $28.3 \%$ of the benthic $\mathrm{N}_{2}$ production (Rysgaard et al. 2004).

\section{DISCUSSION}

\section{Feeding-related controls on copepod-associated microbial nitrogen cycling}

Live Calanus hyperboreus specimens hosted both aerobic and anaerobic $\mathrm{N}$-cycle activities among which denitrification was quantitatively the most important and consistent. The other 2 dissimilatory nitrate reduction pathways, DNRA and DNRN, showed lower rates and varied more strongly between measurement campaigns. Nitrification activity was generally low in live copepods, but gained in importance in aging fecal pellets and carcasses. Several lines of evidence indicate that this pattern of copepod-associated microbial $\mathrm{N}$-cycling is directly and indirectly controlled by the animal's feeding activity and thus the gut filling degree: (1) anaerobic $\mathrm{N}$-cycling was drastically reduced in animals with empty guts, (2) ambient $\mathrm{O}_{2}$ levels did not influence anaerobic $\mathrm{N}$-cycling in algae-fed specimens (i.e. 
their filled guts were anoxic anyway), and (3) freshly released fecal pellets exhibited similar $\mathrm{N}$-cycling as algae-fed copepods.

A copepod gut filled with food is the predestined site for anaerobic $\mathrm{N}$-cycling because it is at least partially anoxic and also rich in labile organic carbon from digestive processes (Tang 2005, Tang et al. 2011). The gut microbial community itself is involved in creating these microenvironmental conditions. First, the aerobic activity of heterotrophic microorganisms in the food promotes gut anoxia (Tang et al. 2011, Heisterkamp et al. 2016), which triggers a shift to anaerobic metabolism in many microorganisms ingested by aquatic invertebrates (Stief et al. 2009, Heisterkamp et al. 2010). Second, the microbial community of the copepod gut contributes to the solubilization of organic food particles through exoenzyme activities (Lawrence et al. 1993). In the light of these microbe-microenvironment interactions, it is not surprising that the rates of anaerobic $\mathrm{N}$ cycling in live copepods were significantly reduced by starving the animals, which probably rendered the gut richer in oxygen and poorer in organic carbon and microbial biomass. Similar results were found for the aquatic larvae of the midge Chironomus plumosus in which denitrification and $\mathrm{N}_{2} \mathrm{O}$ production were exclusively mediated by microorganisms in the gut contents, but not in the gut wall (Stief et al. 2009).

Net $\mathrm{N}_{2} \mathrm{O}$ release was not significantly different in algae-fed, algae-starved, or bacteria-starved specimens of $C$. hyperboreus. However, a very strong and uniform control on both net $\mathrm{N}_{2} \mathrm{O}$ release and nitrification activity was exerted by the ambient $\mathrm{O}_{2}$ level, suggesting that $\mathrm{N}_{2} \mathrm{O}$ was mainly formed through aerobic nitrification. The positive correlation between net $\mathrm{N}_{2} \mathrm{O}$ and $\mathrm{NH}_{4}{ }^{+}$release further suggests that nitrification was stimulated by $\mathrm{NH}_{4}{ }^{+}$accumulating in the incubation bottles. The individual-specific rates of net $\mathrm{N}_{2} \mathrm{O}$ release by algae-fed specimens of $C$. hyperboreus translate into weight-specific rates of 14-18 pmol $\mathrm{N}$ mg wet $\mathrm{wt}^{-1} \mathrm{~d}^{-1}$ that fall within the range of net $\mathrm{N}_{2} \mathrm{O}$ release due to gut denitrification reported for benthic invertebrates (without a shell or exoskeleton) from freshwater and marine habitats of 13-44 and 0.5-23 pmol N mg wet $\mathrm{wt}^{-1} \mathrm{~d}^{-1}$, respectively (Stief et al. 2009, Heisterkamp et al. 2010). In addition, benthic aquatic invertebrates with a shell or exoskeleton host microbial $\mathrm{N}_{2} \mathrm{O}$ production by nitrification in external biofilms (Heisterkamp et al. 2010, 2013, Svenningsen et al. 2012), which also seems likely for live and dead specimens of $C$. hyperboreus.

Freshly released fecal pellets showed a similar pattern of anaerobic N-cycling as algae-fed copepods, with high denitrification and low DNRA and DNRN rates, despite the incubation under oxic conditions. The denitrification activity of 10 fecal pellets was still significantly lower than that of 1 copepod with a filled gut, possibly because (1) only the very center of the released fecal pellets remained anoxic or (2) denitrification in the fecal pellet proceeded under micro-aerobic conditions, but at a significantly lower rate. Oxygen microsensor measurements have previously been made in large crustacean fecal pellets $\left(3.4 \times 10^{9} \mu^{3}\right.$ in volume; Alldredge \& Cohen 1987) and in the boundary layer surrounding the much smaller fecal pellets of Temora longicornis (2.2-10.0 $\times 10^{5} \mu \mathrm{m}^{3}$ in volume; Ploug et al. 2008). Internal anoxia was evident in the large fecal pellets, but could not be inferred for the small fecal pellets. The fecal pellets of $C$. hyperboreus (3.1-10.7 $\times 10^{6} \mu^{3}$ in volume; Urban-Rich 1999, Juul-Pedersen et al. 2006) take an intermediate position, which makes it difficult to estimate whether they were oxic or anoxic in the center. If the freshly released fecal pellets were indeed not anoxic in the center, then denitrification activity may have also persisted under hypoxic conditions (Lloyd 1993). Such 'aerobic denitrification' has been a long-debated N-cycle pathway, but meanwhile studies are accumulating that demonstrate this process convincingly (e.g. Schreiber et al. 2010, Marchant et al. 2017). Aerobic denitrification is facilitated by the constitutive expression of denitrification genes independent of the ambient $\mathrm{O}_{2}$ level and is thus advantageous in environments with fluctuating $\mathrm{O}_{2}$ levels, as may be the case for the guts of aquatic invertebrates (Tang et al. 2011, Heisterkamp et al. 2016).

In carcasses, the feeding-related controls on copepod-associated $\mathrm{N}$-cycling must fade away because food uptake and processing stop and the copepod body disintegrates. This does not mean, however, that $\mathrm{N}$-cycling declines or takes on a different pattern immediately. In fact, within the first $4 \mathrm{~d}$ after death, $\mathrm{N}$-cycling remained remarkably stable and did not experience significant transformations (see below). Only recently, anaerobic N-cycling has been observed in copepod carcasses of different species and geographic origin (Glud et al. 2015, Stief et al. 2017, 2018). The intensity of carcass-associated N-cycling is mainly controlled by the ambient $\mathrm{O}_{2}$ level through variation in the spatial extent of internal anoxia, which is conceptually different from the anoxic gut scenario described above and resembles more the situation in phytodetritus aggregates that sink through different $\mathrm{O}_{2}$ regimes (Klawonn et al. 2015, Stief et al. 2016). 


\section{Contribution by calanoid copepods to pelagic fixed-nitrogen loss}

The relatively high denitrification activity associated with $C$. hyperboreus corresponds to fixednitrogen loss through $\mathrm{N}_{2}$ production. Arctic surface waters are generally well-oxygenated, which will definitely inhibit pelagic fixed-nitrogen loss mediated by free-living microorganisms (Kalvelage et al. 2011, Dalsgaard et al. 2014). Thus, copepods (similar to sinking phytodetritus aggregates) are unique microsites of fixed-nitrogen loss that is otherwise not represented in the water column of Arctic marine ecosystems. However, fixed-nitrogen loss does occur in Arctic marine sediments that are anoxic a few millimetres or centimetres below the surface (Rysgaard et al. 2004). We estimate that during springearly summer, the total denitrification activity associated with all calanoid copepods and their fecal pellets and carcasses is equivalent to $\sim 28 \%$ of the benthic $\mathrm{N}_{2}$ production through denitrification and anammox. Thus, it appears that the copepod-associated fixed-nitrogen loss reaches a dimension that should be taken into account for budgets and models of marine $\mathrm{N}$-cycling in Arctic marine ecosystems.

Our estimate of pelagic denitrification associated with all calanoid copepods can be regarded as conservative because (1) single abundance peaks of adult copepods were ignored in favor of more commonly observed abundance values (Swalethorp et al. 2011), (2) juvenile stages were not considered because their small body size may (or may not) prohibit internal anoxia and thus denitrification activity, (3) in situ abundances of fecal pellets in Disko Bay by far exceed the abundances calculated from individualspecific fecal pellet production rates (Juul-Pedersen et al. 2006, Swalethorp et al. 2011), and (4) calanoid fecal pellets have similar dimensions, despite the large differences in body size (Juul-Pedersen et al. 2006). However, our estimate is only valid for springearly summer (i.e. for approximately one-quarter of the year) when the abundance of calanoid copepods in the water column is high. Taking this short abundance maximum into account, the annual rate of pelagic denitrification associated with all calanoid copepods will amount to $7.5 \mu \mathrm{mol} \mathrm{m} \mathrm{m}^{-2} \mathrm{yr}^{-1}$, which is equivalent to $7.1 \%$ of the annual rate of benthic $\mathrm{N}_{2}$ production (Rysgaard et al. 2004) and thus considerably lower than the $28.3 \%$ estimated for spring-early summer only. Such estimates of the copepod contribution to fixed-nitrogen loss clearly need to be improved by the annual monitoring of copepod abundances and $\mathrm{N}$-cycling rates (ideally in simultaneous studies at the same location), which is a major undertaking in the Arctic.

\section{Contribution by settled fecal pellets and carcasses to benthic nitrogen cycling}

Once released into the water, fecal pellets and the associated microorganisms are exposed to a macroenvironment that is rich in $\mathrm{O}_{2}$ and poor in labile organic carbon and thus almost the inverse of the gut microenvironment. Anaerobic $\mathrm{N}$-cycling remained remarkably stable under these new conditions, but nitrification activity increased strongly with time. From the $\mathrm{O}_{2}$ consumption rate of the C. hyperboreus fecal pellets and the typical C:N ratio of copepod fecal pellets of 7-9 (Morales 1987), it is estimated that nitrification activity can be sustained by $\mathrm{NH}_{4}{ }^{+}$produced through organic matter degradation inside the fecal pellets (Table S6 in the Supplement). Importantly, the strong increase in nitrification activity turned the fecal pellets from net $\mathrm{NO}_{\mathrm{x}}{ }^{-}$sinks into net $\mathrm{NO}_{\mathrm{x}}{ }^{-}$sources. At an estimated sinking velocity of the C. hyperboreus fecal pellets of $\sim 50 \mathrm{~m} \mathrm{~d}^{-1}$ (Urban-Rich 1999, Wassmann et al. 1999), the fecal pellets would sink $200 \mathrm{~m}$ during the experimental aging period of $4 \mathrm{~d}$. Fecal pellets may thus reach the seafloor in many coastal marine areas and still contribute to both benthic nitrification and denitrification.

The $C$. hyperboreus carcasses remained microsites of denitrification and net $\mathrm{NO}_{\mathrm{x}}^{-}$consumption throughout the entire aging period of $4 \mathrm{~d}$. Denitrification rates showed first signs of a decrease (but not statistically significant) in 4-d-old carcasses. The decline of this anaerobic, heterotrophic activity is likely explained by the loss in organic matter content and the potential reduction of internal anoxia. Sinking velocities of small copepod carcasses are $\sim 50-100 \mathrm{~m}$ $\mathrm{d}^{-1}$ (Elliott et al. 2010, Kirillin et al. 2012, Dubovskaya et al. 2015) and thus carcasses settling on the seafloor at shallow sites may persist as microsites of denitrification as is known from diatom aggregates (Marzocchi et al. 2018).

\section{CONCLUSION}

Our results suggest that N-budgets in Arctic marine ecosystems need to include the newly discovered pelagic fixed-nitrogen loss that is associated with live calanoid copepods and their remains in addition to the already known benthic fixed-nitrogen loss that takes place in anoxic sediment layers. Such pelagic 
fixed-nitrogen loss enabled by anoxic microsites has also been discovered for phytodetritus aggregates and copepod carcasses (Glud et al. 2015, Klawonn et al. 2015, Stief et al. 2016), in polar, temperate, and tropical latitudes (Glud et al. 2015, Klawonn et al. 2015, Stief et al. 2016, 2017, 2018, this study), in lowoxygen environments (Stief et al. 2017), and in freshwater ecosystems (Stief et al. 2018). Thus pelagic fixed-nitrogen loss enabled by anoxic microsites is emerging as a widespread phenomenon in various aquatic ecosystems and is consequently also adopted in current models of oceanic N-dynamics (Bianchi et al. 2018).

It can be anticipated that other globally abundant groups of zooplankton (e.g. krill, amphipods, salps, and jellyfish) will also be identified as pelagic hotspots of fixed-nitrogen loss. Anaerobic N-cycling in these hotspots is reinforced by low ambient $\mathrm{O}_{2}$ levels that continue to spread in the open ocean, but also in eutrophic coastal regions (Diaz \& Rosenberg 2008, Schmidtko et al. 2017). Interestingly, evidence is increasing that copepods and other zooplankton are abundant in and around oxygen minimum zones (e.g. Teuber et al. 2013, Hirche et al. 2014), which may allow higher rates of zooplankton-associated fixed-nitrogen loss due to the higher temperatures and lower ambient $\mathrm{O}_{2}$ levels compared with Arctic marine ecosystems. Similarly, substantial zooplankton-associated fixed-nitrogen loss may prevail in coastal areas of temperate zones with longer-lasting periods of high productivity than in the Arctic.

Acknowledgements. This study was financially supported by the European Union's Horizon 2020 Research and Innovation Program (Grant agreement No. 669947; HADESERC) and the Danish National Research Council (FNU; 0602-02276B). We thank Bo Thamdrup, Nina Lundholm, Eva Friis Møller, Rasmus Dyrmose Nørregaard, Sara Harðardóttir, Ole Stecher, and Christian Juncher Jørgensen for fruitful discussions and logistic support. Anni Glud, Rie Pors, Susanne Møller, and Dina Holmgård Skov are acknowledged for technical help and sample analysis.

\section{LITERATURE CITED}

Alldredge AL, Cohen Y (1987) Can microscale chemical patches persist in the sea? Microelectrode study of marine snow, fecal pellets. Science 235:689-691

Auel H, Klages M, Werner I (2003) Respiration and lipid content of the Arctic copepod Calanus hyperboreus overwintering $1 \mathrm{~m}$ above the seafloor at 2,300 $\mathrm{m}$ water depth in the Fram Strait. Mar Biol 143:275-282

Bianchi D, Weber TS, Kiko R, Deutsch C (2018) Global niche of marine anaerobic metabolisms expanded by particle microenvironments. Nat Geosci 11:263-270

Bower CE, Holm-Hansen T (1980) A salicylate-hypochlorite method for determining ammonia in seawater. Can J Fish Aquat Sci 37:794-798

Braman RS, Hendrix SA (1989) Nanogram nitrite and nitrate determination in environmental and biological materials by vanadium(III) reduction with chemiluminescence detection. Anal Chem 61:2715-2718

* Camargo JA, Alonso A (2006) Ecological and toxicological effects of inorganic nitrogen pollution in aquatic ecosystems: a global assessment. Environ Int 32:831-849

Conover RJ (1988) Comparative life histories in the genera Calanus and Neocalanus in high latitudes of the northern hemisphere. Hydrobiologia 167:127-142

*Daase M, Varpe Ø, Falk-Petersen S (2014) Non-consumptive mortality in copepods: occurrence of Calanus ssp. carcasses in the Arctic Ocean during winter. J Plankton Res 36:129-144

* Dalsgaard T, Thamdrup B, Farias L, Revsbech NP (2012) Anammox and denitrification in the oxygen minimum zone of the eastern South Pacific. Limnol Oceanogr 57: 1331-1346

“Dalsgaard T, Stewart FJ, Thamdrup B, De Brabrandere L and others (2014) Oxygen at nanomolar levels reversibly suppresses process rates and gene expression in anammox and denitrification in the oxygen minimum zone off Northern Chile. MBio 5:e01966-e14

*Diaz RJ, Rosenberg R (2008) Spreading dead zones and consequences for marine ecosystems. Science 321:926-929

* Dubovskaya OP, Tang KW, Gladyshev MI, Kirillin G and others (2015) Estimating in situ zooplankton non-predation mortality in an oligo-mesotrophic lake from sediment trap data: caveats and reality check. PLOS ONE 10: e0131431

Elliott DT, Harris CK, Tang KW (2010) Dead in the water: the fate of copepod carcasses in the York River estuary, Virginia. Limnol Oceanogr 55:1821-1834

*Falk-Petersen S, Mayzaud P, Kattner G, Sargent JR (2009) Lipids and life strategy in Arctic Calanus. Mar Biol Res 5: 18-39

Fukuda R, Ogawa H, Nagata T, Koike I (1998) Direct determination of carbon and nitrogen contents of natural bacterial assemblages in marine environments. Appl Environ Microbiol 64:3352-3358

* Füssel J, Lam P, Lavik G, Jensen MM, Holtappels M, Gunter M, Kuypers MMM (2012) Nitrite oxidation in the Namibian oxygen minimum zone. ISME J 6:1200-1209

* García-Robledo E, Corzo A, Papaspyrou S (2014) A fast and direct spectrophotometric method for the sequential determination of nitrate and nitrite at low concentrations in small volumes. Mar Chem 162:30-36

*Gilfillan ES, Vandermeulen JH, Hanson S (1986) Feeding, respiration and excretion of the copepod Calanus hyperboreus from Baffin Bay, including waters contaminated by oil seeps. Arctic 39:158-163

Glud RN, Grossart HP, Larsen M, Tang KW and others (2015) Copepod carcasses as microbial hot spots for pelagic denitrification. Limnol Oceanogr 60:2026-2036

Guillard RR, Ryther JH (1962) Studies of marine planktonic diatoms. 1. Cyclotella nana Hustedt, and Detonula confervacea (Cleve) Gran. Can J Microbiol 8:229-239

*Heisterkamp IM, Schramm A, de Beer D, Stief P (2010) Nitrous oxide production associated with coastal marine invertebrates. Mar Ecol Prog Ser 415:1-9

Heisterkamp IM, Schramm A, Larsen LH, Svenningsen NB, Lavik G, de Beer D, Stief P (2013) Shell biofilmassociated nitrous oxide production in marine molluscs: 
processes, precursors and relative importance. Environ Microbiol 15:1943-1955

*Heisterkamp IM, Schramm A, de Beer D, Stief P (2016) Direct nitrous oxide emission from the aquacultured Pacific white shrimp Litopenaeus vannamei. Appl Environ Microbiol 82:4028-4034

Hirche HJ (1991) Distribution of dominant calanoid copepod species in the Greenland Sea during late fall. Polar Biol 11:351-362

*Hirche HJ, Barz K, Ayon P, Schulz J (2014) High resolution vertical distribution of the copepod Calanus chilensis in relation to the shallow oxygen minimum zone off northern Peru using LOKI, a new plankton imaging system. Deep Sea Res I 88:63-73

Juul-Pedersen T, Nielsen TG, Michel C, Møller EF and others (2006) Sedimentation following the spring bloom in Disko Bay, West Greenland, with special emphasis on the role of copepods. Mar Ecol Prog Ser 314:239-255

Kalvelage T, Jensen MM, Contreras S, Revsbech NP and others (2011) Oxygen sensitivity of anammox and coupled N-cycle processes in oxygen minimum zones. PLOS ONE 6:e29299

Kamp A, Stief P, Bristow LA, Thamdrup B, Glud RN (2016) Intracellular nitrate of marine diatoms as a driver of anaerobic nitrogen cycling in sinking aggregates. Front Microbiol 7:1669

Kirillin G, Grossart HP, Tang KW (2012) Modeling sinking rate of zooplankton carcasses: effects of stratification and mixing. Limnol Oceanogr 57:881-894

Klawonn I, Bonaglia S, Brüchert V, Ploug H (2015) Aerobic and anaerobic nitrogen transformation processes in $\mathrm{N}_{2}$ fixing cyanobacterial aggregates. ISME J 9:1456-1466

Lawrence SG, Ahmad A, Azam F (1993) Fate of particlebound bacteria ingested by Calanus pacificus. Mar Ecol Prog Ser 97:299-307

Lloyd D (1993) Aerobic denitrification in soils and sediments - from fallacies to facts. Trends Ecol Evol 8:352-356

Lotti T, van der Star WRL, Kleerebezem R, Lubello C, van Loosdrecht MCM (2012) The effect of nitrite inhibition on the anammox process. Water Res 46:2559-2569

Madsen SD, Nielsen TG, Hansen BW (2001) Annual population development and production by Calanus finmarchicus, C. glacialis, and C. hyperboreus in Disko Bay, western Greenland. Mar Biol 139:75-93

Marchant HK, Ahmerkamp S, Lavik G, Tegetmeyer HE and others (2017) Denitrifying community in coastal sediments performs aerobic and anaerobic respiration simultaneously. ISME J 11:1799-1812

Marzocchi U, Thamdrup B, Stief P, Glud RN (2018) Effect of settled diatom-aggregates on benthic nitrogen cycling. Limnol Oceanogr 63:431-444

McIlvin MR, Altabet MA (2005) Chemical conversion of nitrate and nitrite to nitrous oxide for nitrogen and oxygen isotopic analysis in freshwater and seawater. Anal Chem 77:5589-5595

Møller EF, Riemann L, Søndergaard M (2007) Bacteria associated with copepods: abundance, activity and community composition. Aquat Microb Ecol 47:99-106

Morales CE (1987) Carbon and nitrogen content of copepod faecal pellets: effect of food concentration and feeding behavior. Mar Ecol Prog Ser 36:107-114

Nielsen LP (1992) Denitrification in sediment determined from nitrogen isotope pairing. FEMS Microbiol Ecol 86: 357-362

Olenina I, Hajdu S, Edler L, Andersson A and others (2006)
Biovolumes and size-classes of phytoplankton in the Baltic Sea. HELCOM Balt Sea Environ Proc 106:1-144

Olli K, Wassmann P, Reigstad M, Ratkova TN and others (2007) The fate of production in the central Arctic Ocean - top-down regulation by zooplankton expatriates? Prog Oceanogr 72:84-113

*Ploug H, Iversen MH, Koski M, Buitenhuis ET (2008) Production, oxygen respiration rates, and sinking velocity of copepod fecal pellets: direct measurements of ballasting by opal and calcite. Limnol Oceanogr 53:469-476

* Rysgaard S, Glud RN, Risgaard-Petersen N, Dalsgaard T (2004) Denitrification and anammox activity in Arctic marine sediments. Limnol Oceanogr 49:1493-1502

* Schmidtko S, Stramma L, Visbeck M (2017) Decline in global oceanic oxygen content during the past five decades. Nature 542:335-339

Schreiber F, Stief P, Gieseke A, Heisterkamp IM, Verstraete W, de Beer D, Stoodley P (2010) Denitrification in human dental plaque. BMC Biol 8:24

* Stief P, Poulsen M, Nielsen LP, Brix H, Schramm A (2009) Nitrous oxide emission by aquatic macrofauna. Proc Natl Acad Sci USA 106:4296-4300

Stief P, Kamp A, Thamdrup B, Glud RN (2016) Anaerobic nitrogen turnover by sinking diatom aggregates at varying ambient oxygen levels. Front Microbiol 7:98

* Stief P, Lundgaard ASB, Morales-Ramirez A, Thamdrup B, Glud RN (2017) Fixed-nitrogen loss associated with sinking zooplankton carcasses in a coastal oxygen minimum zone (Golfo Dulce, Costa Rica). Front Mar Sci 4:152

Stief P, Lundgaard ASB, Treusch AH, Thamdrup B, Grossart HP, Glud RN (2018) Freshwater copepod carcasses as pelagic microsites of dissimilatory nitrate reduction to ammonium. FEMS Microbiol Ecol 94:fiy144

* Svenningsen NB, Heisterkamp IM, Sigby-Clausen M, Larsen LH, Nielsen LP, Stief P, Schramm A (2012) Shell biofilm nitrification and gut denitrification contribute to emission of nitrous oxide by the invasive freshwater mussel Dreissena polymorpha (Zebra mussel). Appl Environ Microbiol 78:4505-4509

* Swalethorp R, Kjellerup S, Dünweber M, Nielsen TG, Møller EF, Rysgaard S, Hansen BW (2011) Grazing, egg production, and biochemical evidence of differences in the life strategies of Calanus finmarchicus, C. glacialis and C. hyperboreus in Disko Bay, western Greenland. Mar Ecol Prog Ser 429:125-144

*Tang KW (2005) Copepods as microbial hotspots in the ocean: effects of host feeding activities on attached bacteria. Aquat Microb Ecol 38:31-40

* Tang KW, Turk V, Grossart HP (2010) Linkage between crustacean zooplankton and aquatic bacteria. Aquat Microb Ecol 61:261-277

Tang KW, Glud RN, Glud A, Rysgaard S, Nielsen TG (2011) Copepod guts as biogeochemical hotspots in the sea: evidence from microelectrode profiling of Calanus spp. Limnol Oceanogr 56:666-672

* Teuber L, Schukat A, Hagen W, Auel H (2013) Distribution and ecophysiology of calanoid copepods in relation to the oxygen minimum zone in the eastern tropical Atlantic. PLOS ONE 8:e77590

Thamdrup B (2012) New pathways and processes in the global nitrogen cycle. Annu Rev Ecol Evol Syst 43: 407-428

* Turner JT (2015) Zooplankton fecal pellets, marine snow, phytodetritus and the ocean's biological pump. Prog Oceanogr 130:205-248 
Urban-Rich J (1999) Release of dissolved organic carbon from copepod fecal pellets in the Greenland Sea. J Exp Mar Biol Ecol 232:107-124

Warembourg FR (1993) Nitrogen fixation in soil and plant systems. In: Knowles R, Blackburn TH (eds) Nitrogen isotope techniques. Academic Press, New York, NY, p 157-180

Wassmann P, Hansen L, Andreassen IJ, Riser CW, Urban-

Editorial responsibility: Antonio Bode,

A Coruña, Spain
Rich J (1999) Distribution and sedimentation of faecal pellets on the Nordvestbanken shelf, northern Norway, in 1994. Sarsia 84:239-252

Y Yamaguchi A, Watanabe Y, Ishida $\mathrm{H}$, Harimoto $\mathrm{T}$ and others (2002) Community and trophic structures of pelagic copepods down to greater depths in the western subarctic Pacific (WEST-COSMIC). Deep Sea Res I 49: 1007-1025

Submitted: January 22, 2018; Accepted: July 17, 2018

Proofs received from author(s): August 15, 2018 